\title{
Perancangan Karakter dan Environment Pilot Project Serial Animasi "Imajinavis"
}

\author{
Abdul Manan Heru Setiawan, Sayatman, dan Didit Prasetyo \\ Departemen Desain Produk, Institut Teknologi Sepuluh Nopember (ITS) \\ e-mail: sayatasik@gmail.com; diditdkv@gmail.com
}

\begin{abstract}
Abstrak - Pengembangan imajinasi dan kreativitas anak merupakan hal yang sangat penting. Kedua hal tersebut membantu anak dalam menciptakan solusi dan peluang bagi permasalahan yang ditemui sehari-hari. Film animasi yang baik dapat mengajarkan bagaimana berlaku sosial, bagaimana menyelesaikan suatu permasalahan, manajemen resiko, dan dapat mengajarkan anak untuk menyukai sesuatu yang positif. Film anak-anak yang memuat konten positif juga cenderung meningkatkan permainan imajinasi dan menjadi guru yang baik bagi anak. Penulis dalam perancangan ini mengerjakan sebuah pilot project serial animasi berjudul "Imajinavis". Serial animasi ini menceritakan tentang kehidupan anak yang berpetualang dengan imajinasinya. Animasi ini ditujukan untuk konsumen usia 6-9 tahun sehingga permasalahan yang dihadapi oleh karakter utama adalah permasalahan seharihari. Pengerjaan animasi ini membutuhkan rancangan karakter dan environment yang menarik agar konten cerita dan contoh pemecahan masalah dapat dengan mudah diterima anak-anak. Karena itu dibutuhkan "Perancangan Karakter dan Environment Pilot Project Serial Animasi 'Imajinavis"' untuk memenuhi kebutuhan produksi serial animasi tersebut. Metode yang digunakan adalah studi literatur, existing, dan observasi untuk menemukan konsep awal rancangan karakter dan environment. Kemudian melakukan beberapa tahap studi eksperimental diikuti dengan in-depth interview untuk menentukan bentuk visual aset sehingga dihasilkan purwarupa rancangan karakter dan environment. Luaran yang dihasilkan berupa rancangan karakter yang memuat: sketsa, model 3D, dan pratayang ekspresi karakter; dan rancangan environment berupa: sketsa dan model 3D.
\end{abstract}

Kata Kunci-Animasi, Desain Environment, Desain Karakter, Imajinasi.

\section{PENDAHULUAN}

TMAJINASI menurut Kamus Besar Bahasa Indonesia I(KBBI) adalah daya berpikir untuk untuk membayangkan atau menciptakan gambaran kejadian berdasarkan pengalaman seseorang. Proses tersebut bermanfaat untuk memanggil memori yang pernah terjadi untuk pemecahan masalah pada suatu situasi. Abdjul menyimpulkan pentingnya imajinasi bagi anak sebagai perangsang pengembangan bidang kognitif, sosial-emosi, bahasa, seni, dan moral[1]. Imajinasi juga penting dalam pengembangan kreativitas anak. Melalui imajinasi seseorang menghubungkan sesuatu yang riil dan imajiner. Proses inilah yang selanjutnya melahirkan suatu kreativitas. Dalam hal ini imajinasi menjadi latar belakang kemunculan suatu kreativitas dan inovasi.

Berdasarkan bentuknya kreativitas dapat dibedakan dalam tujuh jenis kemampuan yaitu: Kemampuan mengenali objek; Kemampuan berbicara; Kemampuan berpikir atau bernalar; Kemampuan berperilaku; Kemampuan menyusun kembali; Kemampuan berimajinasi; serta kemampuan merangkai bentuk. Ke-tujuh kemampuan tersebut saling berhubungan

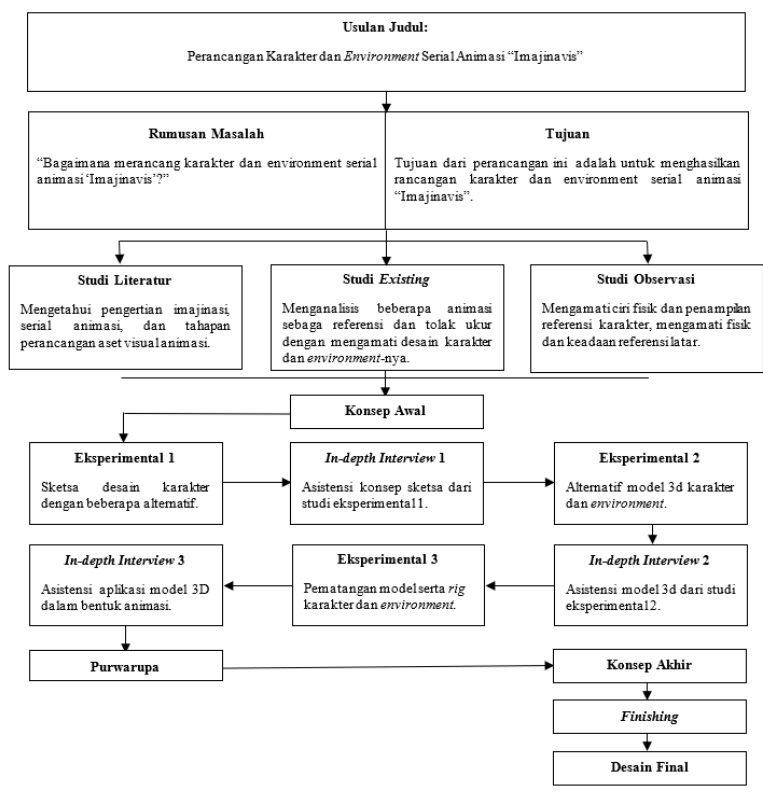

Gambar 1. Bagan Alur Perancangan.

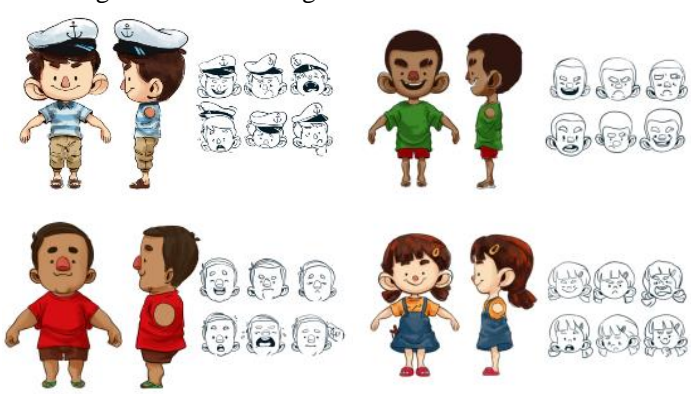

(a)
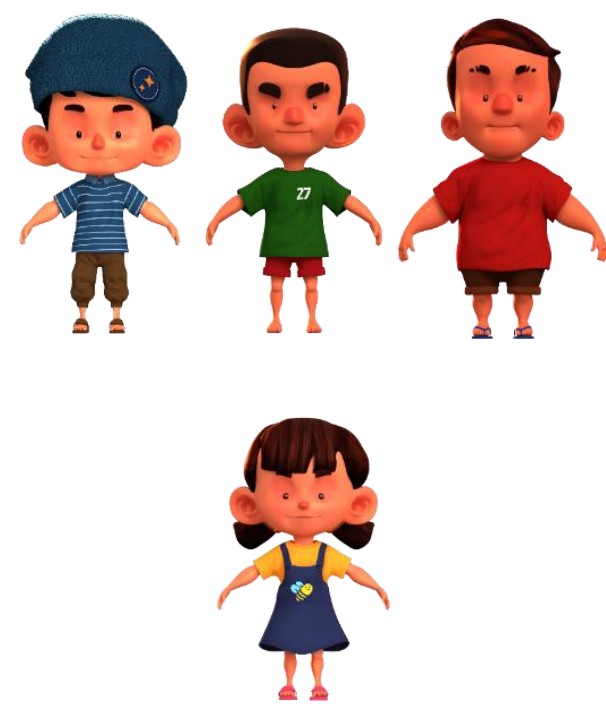

(b)

Gambar 2. Rancangan Karakter Utama; (a) sketsa final, (b) pemodelan 3D final. 


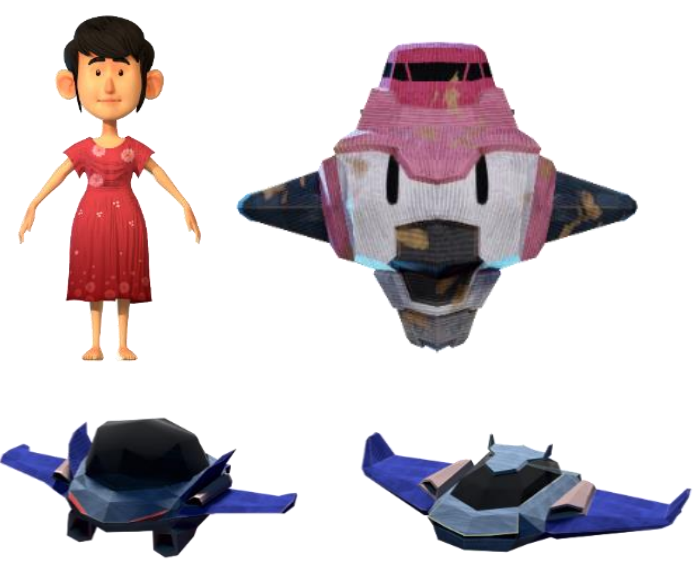

Gambar 3. Beberapa karakter figuran yang dibutuhkan cerita.
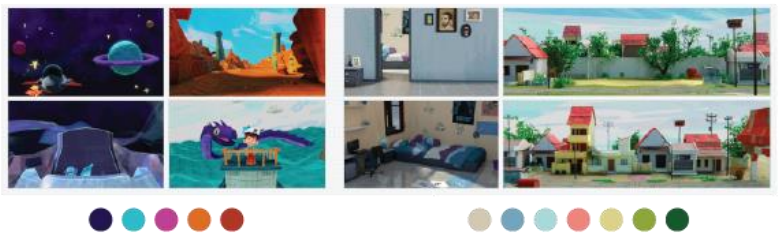

Gambar 4. Kontras desain environment Dunia Imaji dan Dunia Nyata.
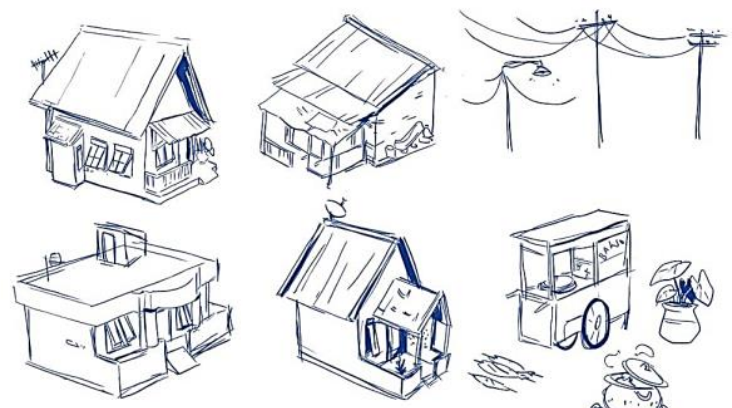

Gambar 5. Beberapa sketsa aset environment dunia nyata.

dan sangat penting dikembangkan dalam diri anak usia sekolah terutama pada usia Taman Kanak-kanak dan Sekolah Dasar. Menurut Muliawan kemampuan-kemampuan tersebut dapat diasah dengan 3 perantara yaitu permainan, umpan balik situasi, serta wahana dan benda sekitar[2].

Kemampuan imajinasi selain dapat diasah dengan perantara-perantara tersebut, juga dapat diasah dengan animasi yang sesuai. Terbukti dari penelitian yang dilakukan oleh Ismail dkk menyimpulkan bahwa video animasi dapat mengembangkan imajinasi dan pemahaman siswa terhadap suatu topik[3]. Diperkuat juga oleh Rashid yang menyebutkan bahwa salah satu sisi positif film animasi adalah dapat meningkatkan kreatifitas dan olah imajinasi anak[4].

Habib dan Soliman juga menjelaskan dalam hasil risetnya bahwa film animasi juga memiliki banyak dampak positif bagi anak. Film animasi yang baik dapat mengajarkan anak bagaimana berlaku sosial, bagaimana menyelesaikan suatu permasalahan, manajemen resiko, dan dapat mengajarkan anak untuk menyukai sesuatu yang positif[5].

Salah satu ragam tema animasi yang digemari anak adalah petualangan. Namun genre ini masih didominasi konten dari luar negeri. Pada platform Youtube dan saluran TV lokal penonton anak-anak lebih mengenal IP luar negeri seperti Boboiboy dari Animonsta dan Upin \& Ipin dari Les' Copaque. Sangat disayangkan kurangnya pelaku industri animasi lokal yang bertema petualangan padahal tema tersebut sangat populer di kalangan anak-anak. Tema petualangan selain menghibur, juga mudah digunakan untuk menyampaikan pesan karena lebih fleksibel dan imajinatif sehingga tidak terikat dengan keterbatasan dunia nyata.

Melalui fleksibilitas tersebut animasi dapat memberi contoh kebebasan anak dalam berkhayal dan menemukan ideide kreatif. Fleksibilitas tersebut juga membuka beragam peluang media-media baru yang dapat digunakan. Misalnya media permainan digital, augmented reality (AR), hingga virtual reality (VR). Dengan memilih pilot project sebagai judul penulis dapat mencoba mengimplementasi produk yang telah dibuat ke dalam media-media baru sebagai pembeda dan inovasi dari produk animasi-animasi sebelumnya. Namun media animasi tidak dapat berdiri sendiri. Animasi membutuhkan karakter dan environment yang mendukung jalannya cerita.

Karena latar belakang tersebut diperlukan perancangan karakter dan environment untuk mendukung jalannya cerita pada pilot project serial animasi "Imajinavis" dengan mengadaptasi unsur kreativitas lokal.

\section{A. Rumusan Masalah}

Bagaimana merancang karakter dan environment serial animasi 'Imajinavis' dengan merepresentasi imajinasi anak?

\section{B. Tujuan}

Menghasilkan rancangan karakter dan environment serial animasi "Imajinavis" dengan merepresentasi imajinasi anak.

\section{TINJAUAN PUSTAKA}

\section{A. Imajinasi}

Imajinasi adalah proses kognitif yang digunakan dalam fungsi mental dan kadang digunakan bersamaan dengan penggambaran psikologis. Menurut Byrne imajinasi didefinisikan demikian karena melibatkan pemikiran tentang berbagai kemungkinan[6].

Menurut Santi Imajinasi merupakan unsur pokok dalam pengembangan kreativitas. Jika anak diberikan kebebasan, anak akan merasa mandiri dan percaya diri dalam berkreasi. Imajinasi juga dapat membantu anak menggali potensi dan mengembangkan minat bakatnya[7].

\section{B. Pilot Project}

Pilot Project adalah pelaksanaan program percontohan yang dirancang sebagai pengujian atau percobaan dalam rangka untuk menunjukkan efektivitas suatu program, mengetahui dampak suatu program dan keekonomisannya[8].

Dalam definisi televisi terdapat istilah pilot episode. Pilot episode adalah episode sendiri dari sebuah serial yang dibuat oleh kreator atau produser untuk menunjukkan dan menjual serial tersebut kepada suatu stasiun TV. Pilot episode berguna untuk menguji apakah suatu serial film akan sukses ketika diluncurkan ke publik.

\section{Perancangan Karakter}

Diringkas dari Tillman ada beberapa tahapan yang diperlukan untuk merancang karakter dengan baik[9]. Tahapan tersebut yaitu:

1) Penentuan archetype karakter,

2) Character story,

3) Bentuk dasar karakter, 


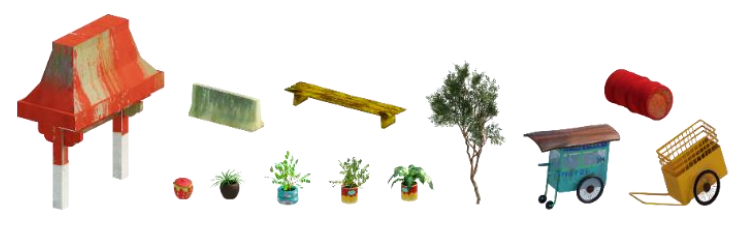

Gambar 9. Aset environment kampung yang telah melalui tahap modeling dan surfacing.

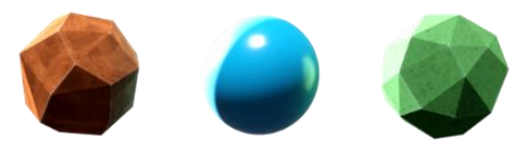

Gambar 10. Material dasar environment Dunia Imaji.

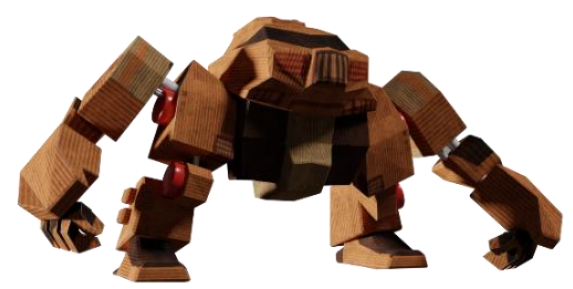

Gambar 11. Salah satu aset bergerak non-karakter pada environment Dunia Imaji.

4) Referensi,

5) Estetika,

6) Turnaround, pose, ekspresi, dan

7) Model Sheet.

\section{Perancangan Environment}

Menurut Hernandez ada beberapa elemen yang penting dalam perancangan environment, di antaranya[10]:

1) Tekstur dan permukaan,

2) Focused Storytelling,

3) Floor Maps dan Shot List,

4) Objek dan Aset,

5) Relasi Karakter,

6) Iconography,

7) Karakteristik,

8) Warna, dan

9) Mood.

\section{METODOLOGI PENELITIAN}

\section{A. Pengumpulan Data}

Pengumpulan data pada penelitian ini menggunakan metode studi literatur, analisis existing, dan observasi sebagai tahap awal penggalian dan penyempurnaan konsep. Hasil dari observasi menjadi referensi rancangan karakter dan environment baik dari segi visual maupun karakteristik behavioral lingkungan setempat. Ketiga metode tersebut menjadi penentu garis besar perupaan rancangan sehingga dapat diterjemahkan dalam studi eksperimental dan diterima oleh narasumber dalam tahap in-depth interview. In-depth interview dilakukan bersama para ahli di bidang terkait untuk mendapat umpan balik sebagai pertimbangan terkait rancangan hasil studi eksperimental. Karakter dan environment yang memenuhi standar akan digunakan dalam pilot project serial animasi Imajinavis.

\section{B. Alur Riset}

Perancangan ini melibatkan beberapa metode penelitian kualitatif sebagai dasar pengambilan data dan perancangan luaran dengan alur seperti dalam Gambar 1.

\section{KONSEP DESAIN}

\section{A. Deskripsi Perancangan}

Desain karakter dan environment merupakan dua elemen penting yang menjadi bahan utama pembuatan suatu serial animasi. Dengan perancangan yang matang, keduanya dapat membantu membangun kualitas animasi sehingga menarik untuk ditonton dan mampu mengikat audience terhadap suatu judul animasi. Penulis, pada perancangan ini berfokus dalam pembuatan aset visual meliputi karakter dan environment untuk pilot episode serial animasi 3D berjudul "Imajinavis". Serial ini Bercerita tentang kehidupan Navis dan temantemannya berpetualang di dunia imaji. Anak-anak sebagai audience diharapkan secara tidak langsung mendapat referensi dan inspirasi tentang penyelesaian masalah seharihari dengan imajinasi masing-masing. Animasi ini membutuhkan sebuah rancangan karakter dan environment yang memperhatikan kesesuaian tema, estetika, dan konsumen.

\section{B. Kriteria Desain}

Dari hasil penelitian yang sudah penulis paparkan pada bab-bab sebelumnya, dapat ditarik beberapa kriteria desain yang dibutuhkan dalam perancangan ini.

\section{1) Kebutuhan Konsumen}

Berdasarkan riset yang telah dikerjakan, penulis mendapati kebutuhan konsumen sebagai berikut:

a) Anak-anak usia 6-9 tahun terutama laki-laki,

b) Memiliki akses media digital seperti Youtube, dan

c) Menyukai animasi bertema petualangan.

2) Kebutuhan Karakter

Penulis dapat mengambil kriteria perancangan karakter dari riset yang dilakukan sebelumnya. Kriteria tersebut yaitu:

a) Menggunakan prosedur perancangan karakter oleh Tillman,

b) Menggunakan exaggeration dengan gaya gambar yang tidak realis secara bentuk,

c) Mengambil elemen-elemen tertentu yang sesuai dengan kebutuhan karakter dari studi observasi untuk karakter anak-anak,

d) Bentukan setiap karakter harus dapat dibedakan hanya dari siluetnya,

e) Material karakter menggunakan teknik non-photo realistic dengan melakukan painting manual pada teksturnya,

f) Simplifikasi karakter dibuat lebih ekstrem karena target audience adalah anak-anak usia 6-9 tahun, dan

g) Masing-masing karakter mempunyai identitas warna agar lebih mudah dikenali.

3) Kebutuhan Environment

Data yang telah didapat dalam riset juga menjadi pedoman penarikan kriteria desain environment yang diinginkan. Kriteria tersebut dapat dijabarkan sebagai berikut:

a) Menggunakan studi observasi sebagai acuan,

b) Simplifikasi desain environment dunia nyata tidak seesktrem pada perancangan karakter untuk memberi kontras antara karakter dan environment.

c) Memperhatikan kontras antara dunia nyata dan dunia 
imaji,

d) Material untuk environment dunia nyata dibuat lebih pucat dan membosankan daripada material dunia imaji,

e) Material dunia imaji lebih berwarna dan lebih terang agar terlihat lebih menarik,

f) Bentukan pada environment dunia imaji menyerupai benda aslinya, tetapi dengan exaggeration pada objekobjek yang tidak dapat dijangkau anak-anak,

g) Bentukan pada environment dunia imaji lebih bebas tetapi dibuat dari material yang menyerupai objek yang lebih dekat dengan anak-anak seperti kardus dan kertas.

\section{Desain Karakter Utama}

Penulis melakukan eksperimentasi konsep dengan membuat sketsa-sketsa berdasarkan hasil studi awal yaitu literatur, eksisting, observasi, serta hasil in-depth interview. Penulis melakukan tiga kali studi eksperimental yang semuanya diikuti oleh in-depth interview kepada pakar industri terkait dapat dilihat pada Gambar 2.

\section{Figuran}

Penulis juga melakukan eksperimental untuk beberapa karakter figuran. Namun karena karakter figuran tidak tampil terlalu banyak, penulis tidak perlu menganalisis terlalu dalam seperti pada Gambar 3.

\section{E. Desain Environment}

Konsep desain environment pada animasi Imajinavis dibagi menjadi dua bagian berdasarkan kategori dunia yaitu dunia nyata dan dunia imaji karena ada kesengajaan untuk memberikan kontras pada dua dunia tersebut. Kontras ini diberikan berdasarkan saran dari narasumber untuk membuat imajinasi lebih terkesan menarik bagi anak-anak dapat dilihat pada Gambar 4.

\section{1) Dunia Nyata}

Konsep desain environment dunia nyata mengadaptasi dari visual perkampungan di Surabaya yang diperoleh dari hasil observasi. Menggunakan gaya semi-realis, environment dunia nyata dibuat dengan warna yang lebih kusam dan tidak mencolok. Bentukan dalam environment ini tetap mendapat exaggeration seperti pada environment dunia imaji dan karakter, namun tidak terlalu mendapat simplifikasi sehingga secara bentukan terlihat lebih detail. Pembedaan ini juga bagian dari metode untuk meningkatkan kontras baik antara karakter dengan environment maupun antara environment dunia imaji dengan dunia nyata. Berikut sketsa yang penulis buat untuk desain environment dunia nyata seperti pada Gambar 5.

Sketsa awal tersebut menjadi dasar gaya visual yang dipilih dari segi bentukan. Namun karena perubahan lokasi dari yang awalnya berfokus pada kampung nelayan menjadi kampung sub-urban di Surabaya, beberapa sketsa yang dibuat tidak dilanjutkan ke tahap modeling dan perlu menambah sketsa dari lokasi yang baru dapat dilihat pada Gambar 6 .

\section{2) Dunia Imaji}

Desain environment untuk dunia imaji dibuat untuk menyerupai material-material yang sering digunakan anakanak seperti kardus, kertas, dan plastik. Material-material tersebut pertama-tama dibuat material dasarnya terlebih dahulu lalu dihubungkan dengan diffuse texture dengan
Tabel 1.

Rencana pengembangan sekunder

\begin{tabular}{llll}
\hline \hline \multicolumn{2}{c}{ Digital } & & \multicolumn{1}{c}{ Konvensional } \\
\hline - & stiker layanan chat & $\bullet$ & Topi dan aksesoris, \\
& daring, & $\bullet$ & Badge dan pin, \\
- & wallpaper perangkat & $\bullet$ & Boneka, \\
& digital, & - & Mainan, \\
- & komik digital, & $\bullet$ & Buku dan komik, \\
- & aplikasi permainan, & $\bullet$ & dan sebagainya. \\
- & animasi full-length, & & \\
- dan sebagainya. & & \\
\hline \hline
\end{tabular}

warna solid untuk variasi. Selain kontras pada materialnya, dunia imajinasi juga secara bentuk dibuat sangat berbeda secara bentuk. Objek-objek pada dunia ini dibuat low poly dengan modifier decimate agar tampak seperti mainan kertas dapat dilihat pada Gambar 7.

Penulis dalam pembuatan eksterior ini juga perlu membuat objek non-karakter yang dapat digerakkan berupa robot. Masing-masing mewakili karakter Navis dan temantemannya. Objek-objek tersebut perlu diberi rig seperti manusia agar dapat bergerak secara humanoid. Objek robot dibuat dengan material yang merepresentasikan kardus, tutup botol, dan sedotan.

\section{F. Konsep Pemodelan dan Surfacing}

Pemodelan 3D pada karakter Navis dan karakter lainnya dikerjakan dengan metode tracing sketsa sehingga ukuran dan proporsinya sesuai dengan sketsa yang telah dibuat. Penulis menggunakan peranti lunak Blender dalam proses 3D mulai dari 3D modeling, surfacing, hingga rigging.

Sedangkan pemodelan environment dibuat dengan teknik box-modeling dengan mengacu visual sketsa tanpa tracing karena akurasi bentukan model tidak terlalu diperlukan. Model dasar tersebut kemudian diberi perlakuan deformasi untuk memberi kesan bentukan kartun yang berlebihan.

Surfacing pada model dan karakter memiliki perlakuan yang hampir sama yaitu dengan mengusahakan permukaan yang merepresentasi benda asli dengan gaya semi-realis. Beberapa objek yang sering muncul dari jarak dekat mendapat detail khusus seperti penambahan normal mapping untuk memerikan kesan permukaan yang tidak rata.

Tekstur setiap model dibuat dengan melakukan painting dari nol atau repainting pada tekstur hasil foto. Hal ini berguna untuk memberikan ciri khas visual yang telah direncanakan sebelumnya.

\section{IMPLEMENTASI DESAIN}

\section{A. Implementasi dalam Animasi}

Karakter dan environment yang telah dibuat kemudian disatukan dalam scene sesuai dengan kebutuhan cerita yang tertera di naskah. Setiap scene diletakkan dalam satu berkas berekstensi .blend yang dapat dipakai untuk beberapa shot. Pada tahap penggabungan scene ini penulis juga mengatur lighting dan penempatan kamera dengan menyesuaikan storyboard dapat dilihat pada Gambar 9.

\section{B. Target Luaran}

Luaran yang dihasilkan berupa pilot project serial animasi yang direncanakan untuk dilanjutkan menjadi serial animasi satu season penuh. Setiap episode animasi Imajinavis 
berdurasi sekitar 7-10 menit termasuk opening dan credit title. Episode total dalam satu musim direncanakan berjumlah 10 episode.

\section{Konsep Distribusi}

Distribusi dari animasi yang telah dibuat sebagaimana tertulis dalam latar belakang adalah melalui media Youtube. Youtube juga mendukung format video baru seperti video 360, karena itu dapat diuji juga efektivitas media imersif tersebut.

Selain itu penting juga promosi di media sosial lain yang juga ramai seperti Instagram dengan fitur pos video atau IGTV yang mendukung format video berdurasi lebih panjang.

\section{Rencana Pengembangan IP}

Sebagai sebuah pilot project, pengerjaan perancangan ini berfokus untuk menunjukkan sebuah konsep dari sebuah ide serial animasi penuh yang telah direncanakan bersama tim. Pilot project ini dapat dilanjutkan dan diproduksi penuh tentunya dengan sumber daya yang cukup.

Pembuatan versi penuh serial animasi Imajinavis akan membutuhkan tambahan aset visual karakter dan environment yang tidak terdapat dalam episode pilot. Pengerjaan aset untuk satu episode diperkirakan sekitar 1-2 minggu dan prosesnya dapat dilakukan paralel dengan proses animasi di setiap episodenya.

Berikut ini lini masa rencana produksi dalam pembuatan animasi Imajinavis dapat dilihat pada Gambar 10.

1) Rencana Pengembangan IP untuk Aplikasi Virtual Reality Imajinavis

Sebagai pilot project diperlukan pengembangan untuk potensi inovasi media-media beru seperti virtual reality (VR). Penulis mencoba mengkonversi aset-aset environment yang telah dibuat untuk animasi ke dalam bentuk virtual reality dengan perangkat lunak pemrograman aplikasi permainan. Virtual reality ini menjadi salah satu pengembangan IP yang menjadi prioritas karena besarnya peluang di masa depan yang dapat dilihat pada Gambar 11.

\section{2) Rencana Pengembangan IP untuk Media Lain}

Sebagai IP kreatif yang terdaftar, karakter dan aset dalam serial animasi Imajinavis dapat dikembangkan ke mediamedia lain dengan aman dan dilindungi hukum. Karakterkarakter dapat dikembangkan menjadi beberapa produk digital dan konvensional seperti pada Tabel 1.

Selain itu dengan proses licensing yang telah dilakukan, terbuka juga peluang-peluang untuk pengembangan seperti endorsement produk melalui sponsor, media sosial, product placement, dan lain sebagainya.

\section{KESIMPULAN DAN SARAN}

\section{A. Kesimpulan}

Masa kanak-kanak menjadi masa penting tumbuh kembang imajinasi seseorang. Imajinasi sebagai dasar tumbuhnya kreativitas pada anak-anak sangat perlu mendapat dorongan agar ke depannya anak dapat menyelesaikan permasalahan-permasalahan dengan cara yang kreatif. Untuk itu anak-anak layak memiliki pilihan tontonan yang menarik dan menyenangkan yang mendukung perkembangan imajinasinya. Film animasi membutuhkan desain karakter dan environment yang menarik sebagai umpan sebelum konsumen mencerna cerita dan kandungan pesannya.

Selain itu karakter juga dapat dikembangkan menjadi media-media lain yang membantu mendorong distribusi suatu proyek animasi. Dengan kemunculan media-media digital baru pengembangan IP menjadi semakin tidak terbatas.

\section{B. Saran}

Penulis pada perancangan ini meninggalkan beberapa pencapaian yang belum dapat terpenuhi. Poin-poin berikut dapat menjadi masukan untuk pengembangan atau penelitian terkait di masa depan.

1) Pendaftaran HKI pada perancangan ini belum dapat dilakukan hingga tahap sertifikasi karena proses yang panjang dan waktu yang lama. Penulis melampirkan beberapa formulir yang dibutuhkan sebagai contoh bagi perancangan-perancangan selanjutnya.

2) Desain karakter yang penulis buat kurang menunjukkan diversitas sosial. Hal ini selain karena kebutuhan cerita yang tidak menuntut keragaman suku, agama, dan ras juga salah satunya karena di lokasi observasi penulis hanya mendapati tatanan masyarakat yang homogen. Pluralisme terutama dalam desain karakter untuk animasi perlu diberikan untuk menanamkan pesan toleransi dan tenggang rasa bagi target penonton.

3) Aplikasi VR yang penulis buat belum maksimal untuk digunakan oleh end-user. Aplikasi tersebut hanya merupakan presentasi semi-dinamis dari beberapa environment yang ada di Imajinavis. Interaktivitas pada permainan tersebut masih sangat terbatas dan tidak memiliki gameplay selayaknya permainan VR yang lain. Untuk pemasaran yang lebih baik aplikasi perlu dibuat sebagai permainan yang utuh agar dapat dinikmati dengan baik oleh pengguna.

4) Aplikasi yang penulis buat belum dapat dimainkan melalui marketplace perangkat VR. Aplikasi tersebut saat ini hanya dapat digunakan dengan bantuan komputer melalui proses sideloading. Pemuatan suatu aplikasi ke dalam marketplace membutuhkan berbagai syarat yang harus dipenuhi untuk kemudian di-review oleh pihak marketplace. Proses ini membutuhkan alokasi waktu sendiri yang relatif lama tergantung kebijakan masing-masing marketplace.

\section{DAFTAR PUSTAKA}

[1] I. Abdjul, "Meningkatkan kemampuan berimajinasi melalui metode bercerita," Universitas Negeri Gorontalo, 2012.

[2] J. U. Muliawan, Mengembangkan Imajinasi Dan Kreatifitas Anak. Yogyakarta, Indonesia: Gava Media, 2016.

[3] M. E. Ismail, I. M. Ismail, H. Othman, and M. H. Amiruddin, "The use of animation video in teaching to enhance the imagination and visualization of student in engineering drawing," in IOP Conference Series Materials Science and Engineering, 2017.

[4] A. Rashid, "Impact of television cartoon channels on children in india," J. Indian Res., vol. 3, no. 2, pp. 64-72, 2015.

[5] K. Habib and T. Soliman, "Cartoons' effect in changing children mental response and behavior," Open J. Soc. Sci., vol. 3, no. 9, pp 248-264, 2015

[6] R. M. J. Byrne, The rational imagination: how people create alternatives to reality (a bradford book). Cambridge, MA: MIT Press, 2007.

[7] D. Santi, Pendidikan Anak Usia Dini - Antara Teori dan Praktik. Jakarta: Indeks, 2009.

[8] Badan Pengkajian dan Penerapan Teknologi, "Laporan akuntabilitas 
kinerja instansi pemerintah (LAKIP) inspektorat BPPT tahun anggaran 2015," Jakarta, 2015.

[9] B. Tillman, Creative Character Design. Waltham, Massachusetts: Focal Press, 2011.
[10] E. A. Hernandez, Set the Action! Creating Backgrounds for Compelling Storytelling in Animation, Comics, and Games. Burlington, Massachusetts: Focal Press, 2012. 